\title{
Heparin and its contribution to the treatment of COVID-19
}

\author{
Heparina e sua contribuição para o tratamento da COVID-19 \\ Heparina y su contribución al tratamiento del COVID-19
}

Received: 09/06/2021 | Reviewed: 09/15/2021 | Accept: 09/21/2021| Published: 09/23/2021

\author{
Tamíres Hillesheim Mittelmann \\ ORCID: https://orcid.org/0000-0002-8576-0070 \\ Universidade Federal da Fronteira Sul, Brazil \\ E-mail: tamiresmittelmann@gmail.com \\ Juliana Baldissera Dors \\ ORCID: https://orcid.org/0000-0003-4862-2258 \\ Universidade Federal da Fronteira Sul, Brazil \\ E-mail: ju.dors@hotmail.com \\ Victória Galletti dos Santos Arraes \\ ORCID: https://orcid.org/0000-0002-5404-0038 \\ Universidade Federal da Fronteira Sul, Brazil \\ E-mail: vicgalletti@gmail.com \\ Graciela Soares Fonseca \\ ORCID: https://orcid.org/0000-0001-9506-0409 \\ Universidade Federal da Fronteira Sul, Brazil \\ E-mail: graciela.fonseca@uffs.edu.br \\ Cesar Andres Diaz Arias \\ ORCID: https://orcid.org/0000-0002-9748-1300 \\ Centro Universitário Claretiano, Brazil \\ Email: cesar.andres.arias@gmail.com
}

\begin{abstract}
The infection caused by SARS-CoV-2 presents changes in the coagulation processes such as venous thromboembolism (VTE) and disseminated intravascular coagulation (DIC) and it has been shown that this coagulopathy is associated by some means with the mortality. Studies suggest that these anticoagulants reduced the mortality of hospitalized patients. However, the studies for this point are not demonstrative, since they are evaluated as multiple variables and the results obtained are not the answer to experimental designs with controlled variables. In most of the cases, the obtained responses are the result of isolated cases or experimental models that do not differentiate statistical data, probably because of the differences related to the study groups. However, in models adjusted for age and sex, the reduction in mortality was statistically significant in patients who were treated with heparins, even when other variables were added to the model. In view of this, there is no consensus regarding the dose and type of anticoagulant, between different countries and entities, but what is most often cited is the use of low molecular weight heparin (LMWH) in a prophylactic dose for all hospitalized patients with the disease. The use of anticoagulants such as heparins has suggested results applicable to the treatment of coagulopathy caused by COVID19, which makes the subject important for the centralization and analysis of the results. In order to continue with the construction of knowledge around this theme, the objective of this work was to review the use of heparins in the treatment of COVID-19.
\end{abstract}

Keywords: Heparin; Coronavirus infections; Pharmacological treatment; Pandemics.

\section{Resumo}

A infeção causada pelo SARS-CoV-2 apresenta alterações nos processos de coagulação como tromboembolismo venoso (TEV) e coagulação intravascular disseminada (CIVD) e foi demonstrado que esse quadro de coagulopatia está associado de alguma maneira com a mortalidade. Estudos sugerem que anticoagulantes diminuíram a mortalidade de pacientes internados. No entanto, os estudos não são demonstrativos, uma vez que são consideradas múltiplas variáveis e os resultados obtidos não são a resposta a planejamentos experimentais com variáveis controladas. Na maioria dos casos, as respostas obtidas são o resultado de casos isolados ou de modelos experimentais que não apresentaram significância estatística, provavelmente, por causa das diferenças relacionadas aos grupos de estudo. No entanto, em modelos ajustados para idade e sexo, a redução na mortalidade foi estatisticamente significativa em pacientes que foram tratados com heparinas, inclusive quando outras variáveis foram adicionadas ao modelo. Frente a isso, não existe um consenso em relação à dose e ao tipo de anticoagulante, entre os diferentes países e entidades, mas o que é citado com mais frequência é o uso da heparina de baixo peso molecular (HBPM) em dose profilática para todos os pacientes internados com a doença. $\mathrm{O}$ uso de anticoagulantes como as heparinas têm sugerido resultados aplicáveis ao tratamento da coagulopatia causada pela COVID-19, o que torna o tema importante para a centralização 
e a análise dos resultados. Com o intuito de continuar com a construção do conhecimento na temática, o objetivo deste trabalho foi realizar uma revisão narrativa sobre o uso das heparinas no tratamento da COVID-19.

Palavras-chave: Heparina; Infecções por coronavírus; Tratamento farmacológico; Pandemias.

\section{Resumen}

La infección por SARS-CoV-2 presenta alteraciones en los procesos de coagulación como tromboembolismo venoso (TEV) y coagulación intravascular diseminada (CID) y se ha demostrado que este cuadro de coagulopatía se asocia de alguna manera con la mortalidad. Los estudios sugieren que los anticoagulantes reducen la mortalidad hospitalaria. Sin embargo, los estudios no son demostrativos, ya que se consideran múltiples variables y los resultados obtenidos no son la respuesta a diseños experimentales con variables controladas. En la mayoría de los casos, las respuestas obtenidas son el resultado de casos aislados o modelos experimentales que no mostraron significancia estadística, probablemente por diferencias relacionadas con los grupos de estudio. Sin embargo, en los modelos ajustados por edad y sexo, la reducción de la mortalidad fue estadísticamente significativa en los pacientes tratados con heparina, incluso cuando se añadieron otras variables al modelo. Ante esto, no existe consenso en cuanto a dosis y tipo de anticoagulante entre diferentes países y entidades, pero lo que se cita con mayor frecuencia es el uso de heparina de bajo peso molecular (HBPM) en dosis profiláctica para todos los pacientes hospitalizados por la enfermedad. El uso de anticoagulantes como las heparinas ha sugerido resultados aplicables al tratamiento de la coagulopatía por COVID19, lo que hace que el tema sea importante para la centralización y análisis de resultados. Para continuar con la construcción de conocimiento sobre el tema, el objetivo de este trabajo fue realizar una revisión sobre el uso de heparinas en el tratamiento del COVID-19.

Palabras clave: Heparina; Infecciones por coronavirus; Tratamiento farmacológico; Pandemias.

\section{Introduction}

Coronaviruses are part of a large group of viruses that are characterized by their crown-like appearance (Cascella et $a l ., 2021)$. They are formed by a nucleus of genetic material, surrounded by a cover with spicules of proteins. Its entire genome is inscribed on a single strand of ribonucleic acid (RNA) and the proteins present on the surface of the virus act as facilitators of its entry into host cells and are related to its pathogenesis (Kumar el al., 2020).

Coronaviruses are responsible for respiratory infections emerging in humans and can cause everything from common colds to more serious diseases such as the Middle East Respiratory Syndrome (MERS) and Severe Acute Respiratory Syndrome (SARS). These viruses are able to cross barriers between species, and can be transmitted from animals to humans in a process called spillover infection (Cascella et al., 2021).

There are seven types of coronaviruses that cause disease in humans. However, three specifically cause more severe respiratory infections: Mers-CoV, which was identified in 2012 as the cause of MERS; SARS-CoV which was identified in 2002 as the cause of the SARS outbreak and SARS-CoV-2, which is the new coronavirus. It was discovered in Wuhan, China on December 31, 2019 as an etiological agent of the disease COVID-19 (Cespedes \& Souza, 2020). The first two cited viruses infected mammals before jumping to humans, dromedary for MERS-CoV and Himalayan palm civet for SARS-CoV. The origin of SARS-CoV-2 is still unknown, but it is postulated that it also came from animals (Cascella et al., 2021).

SARS-CoV and SARS-CoV-2 share $82 \%$ of genomic similarity (Chan et al., 2020). One of its differences is the change in some nitrogenous bases that they express at the structural level. This led to the modification of five of the amino acids responsible for binding the virus to the host's angiotensin-converting enzyme 2 (ACE2) receptors, conferring greater affinity and bond strength. In addition, unlike SARS-CoV, SARS-CoV-2 can use a wide range of proteases that are necessary for the introduction of the virus into the cell, conferring it more probabilities at the introduction phase (Gheblawi et al., 2020). Another difference between the two viruses is the sequence of the Spike protein, since in SARS-CoV-2 there is a cleavage site similar to furin. This cleavage site may have an influence on pathogenicity and viral life cycle (Coutard el al., 2020). The differences presented by SARS-CoV-2, of which it is not yet fully known, may explain the greater potential for spreading the virus compared to SARS-CoV.

The clinical characteristics of SARS-CoV-2 infection range from oligo/asymptomatic conditions to severe pneumonia, including SARS. Faced with this, signs and symptoms include fever (83\% -99\%), cough (59-82\%), asthenia (44-70\%), 
anorexia (40\%), myalgia (11-35\%), dyspnoea (31-40\%), respiratory secretion (27\%), loss of taste and / or smell (more than 80\%) (Dias et al., 2020).

For the aforementioned causes, and due to the lack of knowledge of an effective tool to combat it, the World Health Organization (WHO), on March 11, 2020, declared COVID-19 as a pandemic. In september 2021, the number of cases and deaths already exceeded 218 million and 4 million, respectively, worldwide (World Health Organization, 2021).

To date, there is no drug that presents safe and effective results for specific treatment of COVID-19 (Dias et al., 2020). Furthermore, there are no specific antiviral treatments for SARS-CoV-2 (Cascella et al., 2021) There are already effective vaccines, which are being applied to the world population. However, until the entire population is covered it will take time, which makes it necessary to study possible treatments.

In view of this, it is necessary to urgently identify possible treatment strategies for SARS-CoV-2 infection (Dias et al., 2020). In this context, some drugs used to treat other diseases are being evaluated, through clinical trials, based on their mechanisms of action related to the modulation of the immune system, the genome and the viral structure (Barlow et al., 2020). Some of the medications evaluated are: Ribavirin, Favipiravir, Oseltamivir, Lopinavir/Ritonavir, Remdesivir, Corticosteroids, Interferon, Convalescent serum, Tocilizumab, Chloroquine, Hydroxychloroquine and Heparin (Dias et al., 2020, Barlow et al., 2020). Another study also mentions drugs such as: Arbidol or Umifenovir, Azithromycin and Nitazoxanide (Costa et al., 2020).

However, even though several therapies are being tested, the treatments used so far only promote symptomatic support. Some antiviral drugs are associated with other drugs, when there is a moderate to severe disease severity, which has shown a positive effect on the treatment of the disease course (Costa et al., 2020).

Due to the coagulopathy present in patients with COVID-19, the use of anticoagulants has been discussed. Among anticoagulants, direct oral (DOAC) and vitamin K antagonists (VKA) seem not to be adequate due to the DOAC drug interaction profile and the high instability of the INR TP present in VKA (Ageno et al., 2012, Holbrook et al., 2010, Vivas et al., 2020, Testa et al., 2020). In this context, parenteral heparins do not have multiple drug interactions and are suitable for administration to patients on mechanical ventilation (Testa et al., 2020).

Some studies show that the use of heparin has shown promising results in the treatment of COVID-19 (Ayerbe, Risco $\&$ Ayis, 2020, Tang, Bai, Chen, Gong, Li \& Sun, 2020). Heparin plays an important role in the treatment, since the infection causes coagulation changes, and this coagulopathy is associated with high mortality (Tang, Bai, Chen, Gong, Li \& Sun, 2020). Furthermore, heparin has shown anti-inflammatory action (Porfidia \& Pola, 2020) being another positive point, given that in the course of the disease there is a "cytokine storm", which causes an exacerbated inflammatory response. Another important aspect is the possible antiviral effect described in other studies (Porfidia \& Pola, 2020).

In this context, the objective of this study was to carry out a narrative review on the use of heparins in the treatment of COVID-19.

\section{Results and Discussion}

\subsection{Coagulopathy in COVID-19}

The pathophysiology of the disease caused by SARS-CoV-2 is still not well established. However, it starts with the coupling of the virus to receptors of ACE2 located in type II pneumocytes in the lungs (Gheblawi et al., 2020, Yuki, Fujiogi \& Koutsogiannaki, 2020). This enzyme is also expressed in various locations in the human body such as the intestine, kidneys, cardiovascular system, central nervous system and adipose tissue (Gheblawi et al., 2020). 
In severe cases, the exaggerated inflammatory response, called "cytokine storm", has been one of the main mechanisms of lung injury (Yuki, Fujiogi \& Koutsogiannaki, 2020, Ye, Wang \& Mao, 2020) and is considered one of the main causes of SARS and multiple organ failure (Chousterman, Swirski \& Weber, 2017).

Coagulation dysfunction is also considered a common complication of SARS-CoV-2 pneumonia (Wu et al., 2020). These findings are consistent with the close connection already demonstrated between thrombosis and inflammation (Iba \& Levy, 2018, Jackson, Darbousset \& Schoenwaelder, 2019), two processes that reinforce each other (Marietta et al., 2020). Coagulation changes play an important role in the evolution of COVID-19 to more severe forms and are considered a risk factor for SARS and death (Zheng et al., 2020).

Among coagulation disorders, one of the most reported in pneumonia or SARS by the new coronavirus is VTE, a significant cause of morbidity and mortality. Deep vein thrombosis (DVT), thrombosis associated with central venous catheters and pulmonary thromboembolism (PTE) are types of VTE (Poggiali et al., 2020).

Advanced age, immobilization, obesity, smoking and hospitalization are some of the risk factors for VTE. COVID-19 patients often complain of severe asthenia, fatigue and consequent inactivity. In addition, other risk factors for VTE include hypoxia and sepsis, which are two common features of COVID-19 (Poggiali et al., 2020). In addition, acute infections and respiratory failure are also associated with an increased risk of developing VTE in a transient manner (Barbar et al., 2010).

Those hospitalized for COVID-19 are the example of acute patients with increased risk of VTE (Porfidia \& Pola, 2020). This is because, in general, they have several of the factors that predispose to thromboembolism, such as acute infection, reduced mobility, hypoxia and sepsis (in severe cases), advanced age (in most cases) and hospitalization itself (Poggiali et al., 2020) To estimate the risk of developing VTE in hospitalized patients, use the PADUA prediction score, with a score $\geq 4$ corresponding to the increased risk (Barbar et al., 2010).

Porfidia and Pola (2020) analyzed two outpatient case reports of individuals with COVID-19 who developed VTE. They describe not having found risk factors for this, and they concluded that the criteria used routinely to estimate the risk of VTE in outpatients may not apply well to individuals with COVID-19. In this context, they postulated that the infection can be a precipitating factor, as well as the reduced mobility resulting from social isolation (Porfidia \& Pola, 2020).

In a study conducted in the Netherlands with patients who had COVID-19 pneumonia and reported an incidence of $27 \%$ of VTE (including DVT and PTE), this incidence was confirmed by pulmonary angiography, computed tomography (CT) and/or ultrasonography of the legs. PTE was the most frequent thrombotic complication $(n=25$, which corresponds to $81 \%$ of cases). All patients received at least one standard dose of thromboprophylaxis. The authors reinforce the recommendation to apply pharmacological prophylaxis of thrombosis to all patients with COVID-19 admitted to the intensive care unit (ICU) and suggest increasing prophylaxis to high doses, even in the absence of randomized evidence (Klok et al., 2020).

In another study, conducted in China, a 25\% incidence of DVT was found, assessed by venous ultrasound of the legs, in a total of 81 patients with COVID-19 (Cui et al., 2020). Stoneham et al. (2020) found a 7.7\% incidence of VTE among 274 patients with COVID-19 evaluated in England. Of these, 76.2\% were diagnosed with PTE and 23.8\% with DVT (Stoneham $e t$ al., 2020). In an analysis carried out by Artifoni et al. (2020), in France, 16 of 71 patients diagnosed with COVID-19 developed VTE (22.5\%) despite thromboprophylaxis (Artifoni et al., 2020). Of the 75 patients admitted to the ICU at a hospital in the Netherlands, 23 (30.7\%) had a confirmed diagnosis of VTE; of these 20 had TEP (26.7\%) and 3, DVT (4.0\%) (Beun et al., 2020).

Finally, Wichmann et al. evaluated 12 patients who died by COVID-19. Autopsy revealed DVT in 58\% of them, in whom there was no suspicion of venous thromboembolism before death; PTE was the direct cause of death in 4 patients (Wichmann et al., 2020). 
In addition, it was demonstrated that about $90 \%$ of patients with COVID-19 have baseline D-dimer elevation (>0.5 $\mu \mathrm{g} / \mathrm{mL}$ ), which indicates the participation of coagulation disorders in the pathophysiology of the disease (Stoneham et al., 2020).

In another study, at baseline, patients had a pro-coagulant profile characterized by increased clot strength, platelet contribution to clot strength (PCS), fibrinogen contribution to clot strength (FCS), elevated levels of D-dimer and hyperfibrinogenemia (Ranucci et al., 2020).

Some studies demonstrate a relationship between elevation of D-dimer and VTE. In the study conducted by Stoneham et al, 78\% of patients who developed VTE had a D-dimer greater than $2 \mu \mathrm{g} / \mathrm{mL}$, while only $33 \%$ of patients without VTE presented this value. Thus, the authors suggest that very high levels of D-dimer in people with SARS-CoV-2 infection should increase the clinical suspicion of VTE (Stoneham et al., 2020).

Artifoni et al. pointed as one of their results the positive predictive value for VTE of $44 \%$ when the level of the Ddimer is $\geq 1.0 \mu \mathrm{g} / \mathrm{mL}$ and $67 \%$ for the level of the D-dimer $\geq 3 \mu \mathrm{g} / \mathrm{mL}$. Thus, concentrations of D-dimer greater than $1.0 \mu \mathrm{g} /$ $\mathrm{mL}$ predict the risk of VTE. Another finding was a negative predictive value of $90 \%$ for VTE and $98 \%$ for PTE when baseline D-dimer $<1.0 \mu \mathrm{g} / \mathrm{mL}$ (Artifoni et al., 2020).

In addition, high levels of D-dimer are related to worse prognosis (Tang, Li, Wang \& Sun, 2020, Huang et al., 2020, Zhou et al., 2020). Prothrombin time and D-dimer level at admission were longer in patients who were admitted to the ICU than in patients who were not in the ICU (Huang et al., 2020). Non-survivors revealed significantly higher levels of D-dimer, fibrin degradation, as a result of longer prothrombin time (PT) compared to survivors on admission (Tang, Li, Wang \& Sun, 2020). Multivariable regression showed increasing chances of hospital death associated with advanced age, higher SOFA score and D-dimer greater than $1 \mu \mathrm{g} / \mathrm{mL}$ on admission (Zhou et al., 2020).

With this in mind, the International Society for Thrombosis and Hemostasis (ISTH) recommends measuring D-dimer, prothrombin time and platelet count (in decreasing order of importance) in all patients who present COVID-19 infection. This can help to stratify patients who may need admission and strict monitoring or not. Also, in patients who have a significant increase in D-dimer (which can be arbitrarily defined as a three to four-fold increase), admission to the hospital must be considered even in the absence of other serious symptoms, because this clearly means an increase in generation thrombin (Thachil et al., 2020a).

Other exams, in addition to the D-dimer, which may be altered in people with COVID-19 are leukogram, platelet count, fibrinogen, IL-6, prothrombin time, C-reactive protein (CRP), among others. Leukopenia is common among patients with COVID-19 (Huang et al., 2020), especially lymphocytopenia, which can reach a prevalence of 64.3\% (Li et al., 2020), and has a significant association with the occurrence of VTE (Stoneham et al., 2020). Patients with COVID-19 SARS have increased platelet levels (Ranucci et al., 2020) and higher than patients who have severe pneumonia due to another cause (Yin et al., 2020).

Fibrinogen levels are increased in patients with COVID-19 SARS and are related to the increase in IL-6 (Ranucci et al., 2020). Furthermore, they have a significant association with the occurrence of VTE (Stoneham et al., 2020). However, a study demonstrated a decrease in fibrinogen in non-survivors (Tang, Li, Wang \& Sun, 2020). CRP is high in up to $44.3 \%$ of cases (Li et al., 2020). Finally, the levels of highly sensitive cardiac troponin I, serum ferritin, lactate dehydrogenase and IL-6 were clearly elevated in non-survivors compared to survivors over the clinical course and increased with the deterioration of the disease (Zhou et al., 2020).

The systemic inflammatory response caused by the infection can result in endothelial injury with a consequent increase in the generation of thrombin and reduction of fibrinolysis. In this way, a prothrombotic state called sepsis-induced 
coagulopathy (SIC) that precedes DIC (Nascimento et al., 2020) is installed. In this context, it is known that some critically ill patients with COVID-19 meet the DIC criteria and exhibit laboratory signs of vascular inflammation (Porfidia \& Pola, 2020).

Tang et al. (2020) observed the development of DIC on day 4 in $71.4 \%$ of patients who did not survive the infection compared to DIC in only one patient $(0.6 \%)$ who survived. They concluded that abnormal clotting results are associated with a poor prognosis and that the existence of DIC is common in deaths of people with SARS-CoV-2 pneumonia (Tang, Li, Wang \& Sun, 2020).

According to Levi et al., the available evidence suggests that coagulopathy associated with COVID-19 is a combination of low-grade DIC and localized pulmonary thrombotic microangiopathy, which can have a substantial impact on organ dysfunction in the most affected patients. Therefore, ISTH suggests that monitoring of PT, D-dimer, platelet count and fibrinogen may be useful in determining the prognosis in patients with COVID-19 who require hospitalization (Levi et al., 2020).

Consequently, it became evident that SARS-CoV-2 infection leads to coagulation disorders. COVID-19-induced coagulopathy has a prothrombotic profile, which is demonstrated by laboratory findings and the high prevalence of VTE, which is around 30\% (Klok et al., 2020, Cui et al., 2020, Artifoni et al., 2020, Beun et al., 2020). The pathophysiology is not well defined, but it is postulated that it occurs due to an unregulated immunothrombotic response against SARS-CoV-2 (Nicolai et al., 2020), and patients hospitalized with the disease have the complete Virchow triad: hypercoagulability, stasis (due to bed immobilization) and endothelial injury (by SARS). In this context, the use of anticoagulants may be a viable alternative in the treatment of COVID-19.

\subsection{Anticoagulants under study}

Among the anticoagulants used in patients with COVID-19 are AVK - warfarin or acenocoumarol -, DOAC dabigatran, apixaban, rivaroxaban and edoxaban - and parenteral heparins - LMWH and unfractionated heparin (UFH) (Testa et al., 2020).

The first two classes, AVK and DOAC, are not very suitable for use in patients with infection with the new coronavirus. This is because although DOACs represent the treatment of choice for many conditions, such as stroke prevention and embolism in patients with non-valve atrial fibrillation and VTE prevention and treatment, they have multiple drug interactions (antivirals, antibiotics, anti- hypertensive agents, bronchodilators and immunosuppressants), in addition to being subject to metabolic changes induced by acute disease (Ageno et al., 2012, Holbrook et al., 2012, Vivas et al., 2020, Testa et al., 2020).

Antiviral therapies specifically interact strongly with DOAC, exposing patients to a significant increase in plasma DOAC levels (Vivas et al., 2020, Steffel et al., 2018). As a result, they can cause an unpredictable and unstable anticoagulant effect, exposing patients to the risk of uncontrolled bleeding or thrombotic complications (Testa et al., 2020).

AVK remains the only medication available to prevent valve thrombosis and thromboembolic events in patients with prosthetic heart valves and in those in whom DOAC is contraindicated (Whitlock et al., 2012, Eikelboom et al., 2013). However, they have high instability of TP INR due to the variability of vitamin K metabolism, diet, fasting, co-medications, liver failure and heart failure in patients hospitalized with SARS-CoV-2 (Testa et al., 2020).

Considering the pharmacological characteristics of oral anticoagulant drugs, the multiple pharmacological interactions and the possible need for mechanical ventilation with hospitalization in intensive care units, Testa and collaborators suggest replacing oral anticoagulant therapies (AVK and DOAC) with parenteral heparin to avoid the risk of under/ over treatment, except in patients with cardiac valve prostheses, in whom the choice is AVK. In addition, parenteral administration strongly facilitates antithrombotic treatment in ventilated or intubated patients (Testa et al., 2020). 


\subsection{Heparin}

\subsubsection{Types of Heparin}

Parenteral heparins - UFH and LMWH - have antithrombotic action by indirect inhibition of thrombin, which occurs through their interaction with the antithrombin protein. In addition, they also bind to thrombin and increase factor Xa inactivation. LMWH - in comparison with UFH - have equal efficacy, greater bioavailability from the subcutaneous injection site and the need for less frequent administration (with sufficient administration once or twice a day) (Bauer, 2013).

LMWH should be used with caution in patients with renal failure or with a body weight above $150 \mathrm{~kg}$ (Zehnder, 2017). UFH, on the other hand, requires frequent monitoring with activated thromboplastin time (aPTT) and has a higher resistance profile (Thachil et al., 2020b).

In addition, another drug that also acts as an indirect thrombin inhibitor and is used in the thromboprophylaxis of patients hospitalized with COVID-19 is fondaparinux (Marietta et al., 2020). Fondaparinux is a small pentasaccharide fragment of heparin (Zehnder, 2017).

\subsubsection{COVID-19 indication}

The American Society of Hematology, the Spanish Society of Cardiology, the Italian Society of Thrombosis and Hemostasis (SISET) and the ISTH, as well as the WHO and the Anticoagulation Forum suggest that all patients hospitalized with COVID-19 receive thromboprophylaxis. This recommendation applies to cases in which there are no contraindications, such as increased risk of bleeding, which can be detected in cases of active gastroduodenal ulcer, bleeding in the 3 months before admission, active bleeding or platelet count less than 25-50 × 109 / L (Thachil et al., 2020a, Wang et al., 2020), with mechanical compression being more indicated in these cases (Marietta et al., 2020, Wang et al., 2020).

The anticoagulant most indicated by these societies is heparin, especially LMWH. LMWH is generally the most indicated for reasons such as: less exposure of the healthcare worker to the patient and exposure to bleeding, which would lead to savings in personal protective equipment (PPE), less likelihood of problems with resistance to heparin and no need for frequent laboratory monitoring (Thachil et al., 2020b, Bikdeli et al., 2020). However, in cases of renal impairment and an urgent need for reversibility of the coagulation condition, UFH may be more indicated. However, it cannot yet be said that one type of heparin is better than the other in the treatment itself (Thachil et al., 2020b).

In cases of heparin-induced thrombocytopenia, the American Society of Hematology, recommended that fondaparinux be used. SISET makes no distinction between the use of LMWH, UFH or fondaparinux. In addition, this Society recommends that thromboprophylaxis be administered throughout the hospital stay and maintained for 7-14 days after discharge. It is also necessary that it be performed in outpatients who have a risk factor for VTE (Marietta et al., 2020, Kreuziger et al., 2020).

In this sense, Alessandro et al. also show the need for thromboprophylaxis with low doses of LMWH in all patients hospitalized with COVID-19, according to risk stratification (Casini et al., 2021). Some doctors consider increasing doses of heparin in patients without VTE due to its anti-inflammatory, anti-viral effects and the action in the cytokine storm syndrome (Porfidia \& Pola, 2020).

On the other hand, the Brazilian Society of Cardiology indicates anticoagulant therapy for patients with a confirmed diagnosis of COVID-19 with a severity criterion or more, and the severity criteria are respiratory rate greater than or equal to 30 breaths per minute; arterial $\mathrm{O} 2$ saturation less than or equal to $93 \%$ at rest; the relation between arterial oxygen pressure and inspired oxygen fraction ( $\mathrm{PaO} 2 / \mathrm{FiO} 2)$ less than or equal to 300 and radiological evidence of pulmonary involvement greater than 50\% in 24-48 hours (Soeiro et al., 2020). 
In addition, some studies do not indicate thromboprophylaxis for everyone, but prophylactic doses of LMWH for patients with high levels of D-dimers, inflammation, cytokine storm syndrome, coagulation problems and risk of thromboembolism (Magro et al., 2020, Harenberg \& Favaloro, 2020).

\subsubsection{Actions at COVID-19}

Heparin has potentially an antiarrhythmic, anti-inflammatory, antiviral and anti-thrombotic effect. First, the antiarrhythmic effect in patients with COVID-19 is probably due to the increased activity of the sodium and calcium exchanger. Thus, it reduces ventricular arrhythmias and sudden death (Menezes-Rodrigues et al., 2020). In addition to this cardiac benefit, studies also indicate its ability to reduce inflammation and collagen deposition in the myocardium (Thachil, 2020).

This anti-inflammatory action is not restricted only to the heart, it is also exercised in the respiratory system, improving the condition of hyperinflammation that impairs lung functions (Magro et al., 2020). The accumulation of lymphocytes, which trigger an inflammatory response with monocytes, macrophages and inflammatory cytokines in the pulmonary alveoli can hinder gas exchange and generate SARS (Whyte et al., 2020). Heparin helps to inhibit the migration of neutrophils and leukocytes, which can improve the inflammatory process, decrease the incidence of SARS and increase the efficiency of gas exchange (Thachil, 2020, Costanzo et al., 2020). In a retrospective study with hospitalized patients who had severity criteria, it was seen that the group that used LMWH had lower blood levels of IL-6, pro-inflammatory cytokine, when compared to the control group (Shi et al., 2021), which can be explained by the fact that heparin neutralizes a variety of cationic immune mediators, including IL-6 and IL-8 and their chemotaxis (Lever \& Page, 2012).

Besides the anti-arrhythmic and anti-inflammatory functions, another characteristic of heparin is the possibility of having antiviral action (Conzelmann et al., 2020). This action occurs by inhibiting the entry of the virus into the host cell, since the heparin chain may be able to inhibit endoproteases such as factor Xa, thrombin, furin and catechin. In doing so, the subunits of the Spike proteins, S1 and S2, cannot be cleaved, and the entry of viruses into the host cell is prevented (BelenApak \& Sarialioglu, 2020). However, this action is a hypothesis based on in vitro studies, experimental models and the similarity between SARS-CoV and SARS-CoV-2 (Chan et al., 2020, Thachil, 2020, Conzelmann et al., 2020, Mycroft-Wets, 2020).

Along with, there is the anticoagulant effect of heparin, which has the following benefits:

- The inflammatory condition caused by SARS-CoV-2, caused by the activation of monocytes and endothelial cells resulting from the release of cytokines, results in the circulation of free thrombin, which can activate platelets and activate fibrinolysis. Heparin helps to prevent the formation of thrombosis by binding to antithrombin III and potentiating its inhibitory effect of thrombin and active factor $\mathrm{X}$. Thus, it reduces the risk of pulmonary thromboembolism (Thachil, 2020, Costanzo et al., 2020).

- The "cytokine storm", such as interleukins and alpha tumor necrosis factors, initiate a mechanism that incorporates the activation of endothelial cells, platelets and leukocytes. The interaction between these cells corresponds to the immune response in inflammatory stimuli. This storm, caused by SARS-CoV-2, generates a strong coagulatory effect, leading to the formation of thrombi in different parts of the body, impairing the irrigation of several organs and, consequently, leading to their failure (Menezes-Rodrigues et al., 2020, Costanzo et al., 2020). The anticoagulant action of heparin helps to reverse the thrombotic condition caused by this storm (Menezes-Rodrigues et al., 2020).

- Endothelial cells are often affected by pathogenic invasions. In addition, the release of histones and DNA by injury or apoptosis in ubiquitous cells is another factor that damages the endothelial wall, as histones are toxic to this tissue. 
These two factors tend to worsen the coagulopathy process. Heparin helps to reverse this condition, playing the role of antagonism towards histones and protecting the endothelial wall (Thachil, 2020, Costanzo et al., 2020).

\subsubsection{Effectiveness in studies}

A study, conducted with 449 patients with COVID-19 users and non-users of heparin, evaluated the relationship of mortality in 28 days with the use of heparin and risk of coagulopathy (D-dimers and SIC score). Mortality was reduced in participants who used the anticoagulant and had D-dimers 6 times greater than the normal limit, as well as an SIC score greater than 4 . When the markers were within the normal range, no difference was observed between the two groups (Tang, Bai, Chen, Gong, Li \& Sun, 2020).

In patients with D-dimer markers $<1 \mu \mathrm{g} / \mathrm{mL}$, the incidence of death was slightly higher, but not significantly, and the authors attributed this to the ineffectiveness of heparin in those who are not at risk for VTE, probably. because the formation of clots helps in the compartmentalization and ineffectiveness of the infectious agent (Tang, Bai, Chen, Gong, Li \& Sun, 2020).

In another retrospective study, reduced mortality was also found in heparin users. For its execution, data from the medical records of 2075 patients from 17 hospitals in Spain were used, and heparin was administered in 1734. Its use was associated with lower mortality when the model was adjusted for age and sex, remaining significant when the oxygen saturation $<90 \%$ and temperature $>37^{\circ} \mathrm{C}$ were added to the model and also when all other drugs (hydroxychloroquine, azithromycin, steroids, tocilizumab, a combination of lopinavir with ritonavir and / or oseltamivir) were included as covariates. The authors point out that the findings support that there is a thrombotic component in the development of respiratory discomfort in COVID-19. Among the limitations mentioned, there is non-randomization (Ayerbe, Risco \& Ayis, 2020).

\subsubsection{Dose}

\subsubsection{What do Societies say?}

First, it is worth mentioning that the standard dose of heparin for prophylaxis varies between drugs in the heparin class. Enoxaparin, which is a LMWH, being the most used, for example, has a standard dose of $40 \mathrm{mg}$ subcutaneously (SC) once a day and HNF 5000 UI SC (Orsi et al., 2020, Nissborg \& Wahlgren, 2019). However, the standard dose of LMWH and UFH can be adjusted when taking into account body weight and the presence of chronic kidney disease. Fondaparinux has a standard dose of $2.5 \mathrm{mg}$ via daily SC and can be adjusted when taking into account the presence of chronic kidney disease (Orsi et al., 2020). The intermediate dose of enoxaparin is 4,000 IU via SC every 12 hours (Marietta et al., 2020). In addition, the therapeutic dose of enoxaparin is $1 \mathrm{mg} / \mathrm{kg}$ SC 2 times a day (Orsi et al., 2020).

ISTH recommends prophylactic doses of LMWH for all inpatients with COVID-19 (Thachil et al., 2020a). The Swiss Society of Hematology recommends using a standard dose of LMWH for SC thromboprophylaxis when creatinine clearance is $>30 \mathrm{~mL} / \mathrm{min}$ and UFH when $<30 \mathrm{~mL} / \mathrm{min}, 2$ or 3 times a day via SC. In both cases, the dose increase should be considered in patients over $100 \mathrm{~kg}$ (Casini et al., 2021).

The Italian Society of Thrombosis and Hemostasis (SISET) mentions that LMWH, HNF and fondaparinux can also be used in a standard dose for VTE prophylaxis. In a patient with multiple risk factors for VTE (ie, BMI> 30, previous VTE, active cancer, etc.), the use of LMWH in intermediate doses can be considered. Therapeutic doses of heparin are indicated by society only in cases of diagnosis of VTE or prior to the start of VKA (due to the risk of warfarin-induced skin necrosis in individuals with coagulation disorders, such as protein S or C deficiency) (Marietta et al., 2020).

Brazilian Society of Cardiology addresses that full anticoagulation with the use of LMWH or UFH should be considered in critically ill patients ( $\mathrm{RF} \geq 30 \mathrm{rpm}, \mathrm{SatO} 2 \leq 93 \%, \mathrm{PaO} 2$ / $\mathrm{FiO} 2 \leq 300$, pulmonary radiological involvement> $50 \%$ in $24-48$ h). Prophylactic doses of LMWH or UFH should always be considered for patients with a high risk of 
hospitalized VTE. Prophylaxis should be extended for up to 45 days in patients with reduced mobility, cancer, previous VTE and high D-dimer twice above the upper limit (Soeiro et al., 2020).

Brazilian Society of Thrombosis and Hemostasis addresses the use of LMWH in a standard dose of thromboprophylaxis adjusted for body weight and renal function in hospitalized patients. Alternatively, UFH and fondaparinux can be used in patients with heparin-induced thrombocytopenia. Remembering that in case of contraindication it should not be used. The duration of thromboprophylaxis should last for the entire hospitalization period, with 7 days being the minimum period. After hospital discharge, prophylaxis should be maintained in patients at high risk of VTE or who have reduced mobility. With regard to VTE therapy, society recommends LMWH and, alternatively, one can use UFH and Fondaparinux in therapeutic doses (Orsi et al., 2020).

Spanish Society of Cardiology addresses that prophylactic doses of LMWH should be used in patients without severity criteria (refractory respiratory failure and / or hemodynamic instability) and who do not have a high thromboembolic risk. Intermediate doses should be used in patients without severity criteria and who have a high thromboembolic risk or in patients who have severity criteria but do not have a high thromboembolic risk. Anticoagulant doses of LMWH should be used in patients with criteria of severity and high thromboembolic risk (Vivas et al., 2020).

The prophylaxis for thromboembolic disease recommended by the Spanish Society of Thrombosis and Hemostasis (SETH) is done with prophylactic doses of LMWH that vary with the existence of a risk factor for thrombosis or not. Society considers that risk factors are forms of severe COVID-19 with the following changes: C-Reactive Protein (CRP)> $150 \mathrm{mg} / \mathrm{L}$; D-dimer> $1500 \mathrm{ng} / \mathrm{ml}$; Ferritin> $1000 \mathrm{ng} / \mathrm{ml}$; Lymphocytopenia <800 × 106 / L; IL-6> 40 pg / ml; dimer D> $3000 \mathrm{ng} / \mathrm{ml}$; personal or family history of venous thrombotic disease; personal history of arterial thrombotic disease; known biological thrombophilia; recent surgery; gestation; and hormone replacement therapy. Therefore, the Society indicates that patients hospitalized with COVID-19 and the presence of at least one of the risk factors for thrombosis should receive LMWH in a prophylactic dose adjusted for weight unless there is a contraindication (Sociedad Española de Trombosis y Hemostasia, 2020).

In case of patients who are allergic to heparin or heparin-induced thrombocytopenia, fondaparinux should be used. If they do not have a risk factor: doses of $2.5 \mathrm{mg} / 24 \mathrm{~h} \mathrm{SC}$ if the creatinine clearance is $>50 \mathrm{~mL} / \mathrm{min}$. If they have a risk factor: $1.5 \mathrm{mg} / 24 \mathrm{~h} \mathrm{SC}$ if the creatinine clearance is $<50 \mathrm{and}>20 \mathrm{~mL} / \mathrm{min}$; doses of $5 \mathrm{mg} / 24 \mathrm{~h}$ SC if the creatinine clearance is $>50$ $\mathrm{mL} / \mathrm{min} ; 2.5 \mathrm{mg} / 24 \mathrm{~h} \mathrm{SC}$ if creatinine clearance is $<50 \mathrm{and}>20 \mathrm{~mL} / \mathrm{min}$. Finally, if the creatinine clearance is $<20 \mathrm{~mL} /$ min, the use of fondaparinux is contraindicated (Sociedad Española de Trombosis y Hemostasia, 2020).

Thromboprophylaxis must be maintained until discharge, in both. After discharge, LMWH will be maintained at the usual prophylaxis dose in patients who must remain bedridden or with restricted walking or with persistent factors with a higher risk of thrombosis for at least a week or until they obtain adequate mobility (Sociedad Española de Trombosis y Hemostasia, 2020).

In case of suspected PTE, an angiotomography should be performed urgently to confirm the diagnosis. If the diagnosis of PTE or DVT is confirmed, LMWH should be started at therapeutic doses. If the patient with PTE and / or DVT is allergic to heparin or heparin-induced thrombocytopenia, fondaparinux should be used in doses of: $5 \mathrm{mg} / 24 \mathrm{~h} \mathrm{SC}$ if $<50 \mathrm{~kg}$ and creatinine clearance> $50 \mathrm{~mL} / \mathrm{min} ; 7.5 \mathrm{mg} / 24 \mathrm{~h} \mathrm{SC}$ if 50-100 kg and creatinine clearance $>50 \mathrm{~mL} / \mathrm{min} ; 10 \mathrm{mg} / 24 \mathrm{~h} \mathrm{SC}$ if $>100 \mathrm{~kg}$ and creatinine clearance $>50 \mathrm{~mL} / \mathrm{min}$ and $5 \mathrm{mg} / 24 \mathrm{~h} \mathrm{SC}$ if creatinine clearance is $<50$ and $>20 \mathrm{~mL} / \mathrm{min}$ (Sociedad Española de Trombosis y Hemostasia, 2020).

The society recommends that patients diagnosed with PTE or DVT, maintain anticoagulant treatment for a minimum period of 3 to 6 months. The treatment of choice after discharge will be LMWH at an anticoagulant dose every 24 hours (Sociedad Española de Trombosis y Hemostasia, 2020). 
Finally, with regard to the use of UFH, society recommends that, in the case of hemodynamic instability or anticipation of immediate invasive procedures, it should be used in continuous infusion, adjusting the dose with APTT (Sociedad Española de Trombosis y Hemostasia, 2020).

\subsubsection{What do the studies indicate?}

The dosage of heparin used in the treatment of COVID-19 varies from one study to another. In a study carried out with 449 patients (181 women and 268 men) with COVID-19 in severe condition, 28-day mortality between heparin users and non-users was compared, with stratification by the SIC score or result of D-dimer. In the survey, 99 patients (22\%) received heparin for 7 days or more. Of these 99 patients, 94 received enoxaparin at doses of 40-60 mg / day and 5 received UFH at doses of 10,000-15,000 U / day. Among the 99 patients who received heparin for 7 days or more, 30 died within 28 days and of the 350 patients who did not receive heparin or had heparin treatment for less than 7 days, 104 died within 28 days. The study resulted in no difference in mortality between users and non-users of heparin, however it found that the mortality of users of heparin was lower than that of non-users in patients with an SIC score $\geq 4$ or D-dimer> 6 times the upper limit of normal . They conclude by saying that the use of heparin is associated with better prognosis in critically ill patients with coagulopathy (Tang, Bai, Chen, Gong, Li \& Sun, 2020).

The article by Barnes et al. aims to address the guidelines related to the use of anticoagulant therapies in patients with COVID-19, determined by the Anticoagulation Forum, which is a North American organization of anticoagulation providers (Barnes et al., 2020). The article regarding the dosage used, recommends that all non-critical hospitalized patients (who are not in the ICU) with COVID-19 should receive prophylaxis for VTE in a standard dose. Patients admitted to the ICU, that is, critical patients, should receive higher doses of prophylaxis for VTE, for example, enoxaparin $40 \mathrm{mg}$ SC twice daily, enoxaparin $0.5 \mathrm{mg} / \mathrm{kg} \mathrm{SC}$ twice daily, heparin $7500 \mathrm{SC}$ units three times a day or infusion of low intensity heparin (Barenes $e t$ al., 2020, Obi et al., 2019, Obi et al., 2020). With regard to hospital discharge, the article suggests that extended prophylaxis is not necessary for all patients with COVID-19, thus requiring a multidisciplinary discussion at or near discharge, to determine the relevance of maintaining prophylaxis or not. (Barnes et al., 2020).

Barrett et al. (2020) in response to the recommendations of the ISTH, brought the recommendation of making systemic anticoagulation with UFH for patients hospitalized with COVID-19, since the risk of VTE and DIC is very high among them. They use as arguments for systemic anticoagulation the fact that patients have a state of hypercoagulability, that many have heparin resistance, high levels of fibrinogen (which reduce the effectiveness of prophylactic doses) and the lack of randomized clinical trials that compare prophylactic doses versus therapeutic doses. Regarding the use of UFH over LMWH, they state that in the case of PTE and the need for thrombolysis, the action of UFH can be reversed and that of LMWH, not predisposing to a greater chance of bleeding, and also that the SARS from COVID- 19 is associated with renal failure, with LMWH being more harmful in this case (Barrett et al., 2020).

\section{Conclusion}

Evidence indicates that SARS-CoV-2 infection leads to coagulation disorders, such as VTE and DIC. It has been shown that approximately $90 \%$ of patients with increased D-dimer had coagulation disorders with significant association rates. On the other hand, most studies agree that concentrations greater than $1 \mu \mathrm{g} / \mathrm{mL}$ of D-dimer are more likely to have some type of thrombosis.

Among the significant indices, those presented by PTE stand out, showing the highest percentages of incidence in the studies carried out, followed by VTE and DVT respectively. The latter was also cited as the cause of death in patients where thromboembolism was not suspected by the currently used methodologies that question the procedures in this regard in patients 
with COVID-19. In patients who had prophylactic thrombus indications, the indications suggest maintaining the usual anticoagulant with periodic monitoring, and regular measurement of coagulation in patients with COVID-19 is important during treatment.

However, thromboprophylaxis appears to be a promising alternative for patients with COVID-19. The studies carried out show that the use of heparin in patients with COVID-19 brought improvements in the clinical course, being regularly supported in the literature. However, different types of coagulants are being used, but what is most often cited is the use of parenteral heparins. In this context, most studies indicate prophylactic doses of LMWH for all patients hospitalized with COVID-19. Some entities even recommend maintaining anticoagulant treatment for up to six months after discharge in patients previously diagnosed with PTE or DVT.

Several aspects of the new disease need to be clarified in order to have more conclusive results, as well as the need for randomized clinical trials that compare the use of LMWH and UFH and also prophylactic doses versus therapeutic doses, since there is a lack of studies and existing ones are limited because they are not randomized and have a retrospective observational character.

\section{References}

Ageno, W., Gallus, A.S., Wittkowsky, A., Crowther, M., Hylek, E. M. \& Palareti, G. (2012). Oral Anticoagulant Therapy. Chest, 141 (2), e44S-e88S. https://doi.org/10.1378/chest.11-2292

Artifoni, M., Danic, G., Gautier, G., Gicquel, P., Boutoille, D., Raffi, F., Néel, A. \& Lecomte, R. (2020). Systematic assessment of venous thromboembolism in COVID-19 patients receiving thromboprophylaxis: incidence and role of D-dimer as predictive factors. J Thromb Thrombolysis, 50 (1), 211-6. https://doi.org/10.1007/s11239-020-02146-z

Ayerbe, L., Risco, C. \& Ayis, S. (2020). The association between treatment with heparin and survival in patients with Covid-19. J Thromb Thrombolysis, 50 (2), 298-301. https://doi.org/10.1007/s11239-020-02162-z

Barbar, S., Noventa, F., Rossetto, V., Ferrari, A., Brandolin, B., Perlati, M., Bon, E. de., Tormene, D., Pagnan, A. \& Prandoni P. (2010). A risk assessment model for the identification of hospitalized medical patients at risk for venous thromboembolism: the Padua Prediction Score: Padua Prediction Score. Journal of Thrombosis and Haemostasis, 8 (11), 2450-7. http://dx.doi.org/10.1111/j.1538-7836.2010.04044.x

Barlow, A., Landolf, K. M., Barlow, B., Yeung, S. Y. A., Heavner, J. J., Claassen, C. W. \& Heavner, M. S. (2020). Review of Emerging Pharmacotherapy for the Treatment of Coronavirus Disease 2019. Pharmacotherapy, 40 (5), 416-37. https://doi.org/10.1002/phar.2398

Barnes, G. D., Burnett, A., Allen, A., Blumenstein, M., Clark, N. P., Cuker, A., Dager, W. E., Deitelzweig, S. B., Ellsworth, S., Garcia, D., Kaatz, S. \& Minichiello, T. (2020). Thromboembolism and anticoagulant therapy during the COVID-19 pandemic: interim clinical guidance from the anticoagulation forum. J Thromb Thrombolysis, 50 (1):72-81.https://doi.org/10.1007/s11239-020-02138-z

Barrett, C. D., Moore, H. B., Yaffe, M. B. \& Moore, E. E. (2020). ISTH interim guidance on recognition and management of coagulopathy in COVID-19: A comment. J Thromb Haemost, 18 (8), 2060-3. http://dx.doi.org/10.1111/jth.14860

Bauer, K. A. (2013). Pros and cons of new oral anticoagulants. Hematology. Hematology Am Soc Hematol Educ Program, (1), 464-70. https://doi.org/10.1182/asheducation-2013.1.464

Belen-Apak, F. B. \& Sarialioglu, F. (2020). The old but new: Can unfractioned heparin and low molecular weight heparins inhibit proteolytic activation and cellular internalization of SARS-CoV2 by inhibition of host cell proteases? Medical Hypotheses, 142:109743. https://doi.org/10.1016/j.mehy.2020.109743

Beun, R., Kusadasi, N., Sikma, M., Westerink, J., Huisman, A. (2020) Thromboembolic events and apparent heparin resistance in patients infected with SARS-CoV-2. Int J Lab Hematol, 42 (S1), 19-20. http://dx.doi.org/10.1111/ijlh.13230

Bikdeli, B., Madhavan, M. V., Jimenez, D., Chuich, T., Dreyfus, I., Driggin, E., Der Nigoghossian, C., Ageno, W., Madjid, M., Guo, Y., Tang, L.V., Hu, Y., Giri, J., Cushman, M., Quéré, I., Dimakakos, E. P., Gibson, C. M., Lippi, G., Favaloro, E. J., Fareed, J., Caprini, J. A., Tafur, A. J., Burton, J. R., Francese, D. P., Wang, E. Y., Falanga,A., McLintock, C., Hunt, B. J., Spyropoulos, A. C., Barnes, G. D., Eikelboom, J. W., Weinberg, I., Schulman, S., Carrier, M., Piazza, G., Beckman, J. A., Steg, P. G., Stone, G. W., Rosenkranz, S., Goldhaber, S. Z.,Parikh, S. A., Monreal, M., Krumholz, H. M., Konstantinides, S. V., Weitz, J. I. \& Lipfor G. Y. H. (2020). COVID-19 and Thrombotic or Thromboembolic Disease: Implications for Prevention, Antithrombotic Therapy, and Follow-Up. Journal of the American College of Cardiology, 75 (23), 2950-73. https://www.onlinejacc.org/content/75/23/2950

Cascella, M., Rajnik, M., Aleem, A., Dulebohn, S. C. \& Di Napoli, R. (2021). Features, Evaluation, and Treatment of Coronavirus (COVID-19). StatPearls Publishing. https://www.ncbi.nlm.nih.gov/books/NBK554776/

Casini, A., Alberio, L., Angelillo-Scherrer, A., Fontana, P., Gerber, B., Graf, L., Inga, H., Wolfang, K., Johanna, A. K. H., Thomas, L., Maria, M., Michael, N., Jan-Dirk, S., Dimitrios, T., Walter, W. \& Lars M. A. (2021). Thromboprophylaxis and laboratory monitoring for in-hospital patients with Covid-19 - a Swiss consensus statement by the Working Party Hemostasis. Swiss Med Wkly. https://doi.emh.ch/smw.2020.20247

Cespedes, M. S \& Souza, J. C (2020). SARS-CoV-2: uma revisão para o clínico. https://preprints.scielo.org/index.php/scielo/preprint/view/26/version/30 
Chan, J. F. W., Kok, K. H, Zhu, Z., Chu, H., To, K. K. W., Yuan, S. \& Yuen, K-Y. (2020). Genomic characterization of the 2019 novel human-pathogenic coronavirus isolated from a patient with atypical pneumonia after visiting Wuhan. Emerging Microbes \& Infections, 9 (1), 221-36. https://www.tandfonline.com/doi/full/10.1080/22221751.2020.1719902

Chousterman, B. G., Swirski, F. K. \& Weber, G. F. (2017). Cytokine storm and sepsis disease pathogenesis. Semin Immunopathol, 39 (5), 517-28. https://doi.org/10.1007/s00281-017-0639-8

Conzelmann, C., Müller, J. A., Perkhofer, L., Sparrer. K. M., Zelikin, A. N., Münch, J. \& Kleger, A. (2020). Inhaled and systemic heparin as a repurposed direct antiviral drug for prevention and treatment of COVID-19. Clin Med, 20 (6), e218-21. https://doi.org/10.7861/clinmed.2020-0351.

Costa. A. L. E., Branco, A. C., Dzik, A., Link, C., Coelho, C. V. F. G., Voget, J. M., Leuzz, L. F. A., Amaral, M. E. B., Badaloti, M., Martins, M. W. P. B., Valadares, N. P. B., Sasb, N. A, Costa, P. T. V., Petracco, R. G., Nogueira, S., Mattiello, S., Resende, S. de S., Dzik, T. E. \& Carvalho, W. de A .P. de. (2020). Tratamento Coronavírus. In: Salgueiro LL. Interfaces: Reprodução Humana e Covid-19. Sociedade Brasileira de Reprodução Assistida, 130 -135. https://sbra.com.br/wp-content/uploads/2020/05/SBRA-e-Covid-19.pdf

Costanzo, L., Palumbo, F. P., Ardita, G., Antignani, P. L., Arosio, E. \& Failla, G. (2020). Coagulopathy, thromboembolic complications, and the use of heparin in COVID-19 pneumonia. Journal of Vascular Surgery: Venous and Lymphatic Disorders, 8 (5), 711-6. https://doi.org/10.1016/j.jvsv.2020.05.018

Coutard, B., Valle, C., Lamballerie, X. de, Canard, B., Seidah, N. G. \& Decroly, E. (2020). The spike glycoprotein of the new coronavirus 2019-nCoV contains a furin-like cleavage site absent in $\mathrm{CoV}$ of the same clade. Antiviral Research, 176, 104742. https://doi.org/10.1016/j.antiviral.2020.104742

Cui, S., Chen, S., Li, X., Liu, S. \& Wang, F. (2020) Prevalence of venous thromboembolism in patients with severe novel coronavirus pneumonia. J Thromb Haemost, 18 (6), 1421-4. http://dx.doi.org/10.1111/jth.14830

Dias, V., Carneiro, M., Vidal, C., Corradi, M., Brandão, D., Cunha, C., Chebabo, A., Oliveira, P. R. D. de, Michelin, L., Rocha, J. L. L., Waib, L. F., Carrilho, C. M., Lobo, S. M. A., Oliveira, M. C.de, Nunes, R. R., Diego,L. A.dos S., Santos, A. S., Muglia, M. V., Souza Jr., A. S.de, Escuissato, D., Neto, C. A., Chatkin, J. M., Martins, R., Maurici, R., Costa, S. F., Alves, J. S., Nascimento, M. M. do. \& Moura-Neto, J. A., (2020). Orientações sobre Diagnóstico, Tratamento e Isolamento de Pacientes com COVID-19. J. Infect. Control, 2 (9), 58-77. https://infectologia.org.br/wp-content/uploads/2020/07/orientacoessobre-diagnostico-tratamento-e-isolamento-de-pacientes-com-covid-19.pdf

Eikelboom, J. W., Connolly, S. J., Brueckmann, M., Granger, C. B., Kappetein, A. P., Mack, M. J., Jon, B. C. S., Kevin, D., Jeffrey, F., Kelly G., Ruth H., Yasser K., Maximilian, T., Hugo M., Jens-Uwe, V., Maarten, L. S. \& Frans, V. de W. (2013). Dabigatran versus Warfarin in Patients with Mechanical Heart Valves. N Engl J Med, 369 (13):1206-14. DOI: 10.1056/NEJMoa1300615

Gheblawi, M., Wang, K., Viveiros, A., Nguyen, Q., Zhong, J-C., Turner, A. J., Raizada, M. K., Grant, M. B \& Oudit, G. Y. (2020). Angiotensin-Converting Enzyme 2: SARS-CoV-2 Receptor and Regulator of the Renin-Angiotensin System: Celebrating the 20th Anniversary of the Discovery of ACE2. Circ Res, 126 (10), 1456-74. https://doi.org/10.1161/CIRCRESAHA.120.317015

Harenberg, J. \& Favaloro, E. (2020) COVID-19: progression of disease and intravascular coagulation - present status and future perspectives. Clinical Chemistry and Laboratory Medicine (CCLM), 58 (7), 1029-36. https://doi.org/10.1515/cclm-2020-0502

Holbrook, A., Schulman, S., Witt, D. M., Vandvik, P. O., Fish, J., Kovacs, M. J., Svensson, P. J., Veenstra, D. L., Crowther, M. \& Guyatt, G. H. (2012). Evidence-Based Management of Anticoagulant Therapy. Chest, 141 (2), e152S-e184S. https://doi.org/10.1378/chest.11-2295

Huang, C., Wang, Y., Li, X., Ren, L., Zhao, J., Hu, Y., Zhang, L., Fan, G., Xu, J., Gu, X., Cheng, Z., Yu, T., Xia, J., Wei,Y., Wu, W., Xie, X., Yin, W., Li, H., Liu, M., Xiao, Y., Gao, H., Guo, L., Xie, J., Wang, G., Jiang, R., Gao, Z., Jin, Q., Wang, J., Cao, B. (2020). Clinical features of patients infected with 2019 novel coronavirus in Wuhan, China. The Lancet, 395 (10223), 497-506. https://doi.org/10.1016/S0140-6736(20)30183-5

Iba, T. \& Levy, J. H. (2018). Inflammation and thrombosis: roles of neutrophils, platelets and endothelial cells and their interactions in thrombus formation during sepsis. J Thromb Haemost, 16 (2), 231-41. https://doi.org/10.1111/jth.13911

Jackson, S. P., Darbousset, R. \& Schoenwaelder, S.M. (2019). Thromboinflammation: challenges of therapeutically targeting coagulation and other host defense mechanisms. Blood, 133 (9), 906-18. https://doi.org/10.1182/blood-2018-11-882993

Kumar, D., Malviya R. \& Sharma P. (2020). Corona Virus: A Review of COVID-19 History and Origin. Eurasian Journal of Medicine and Oncology, 4 (1), 8-25

Klok, F. A., Kruip, M. J. H. A., Van der Meer, N. J. M., Arbous, M. S., Gommers, D. A. M. P. J., Kant, K. M., Kaptein, F. H. J., Paassen, J. van., Stals, M. A. M., Huisman, M. V. \& Endeman, H. (2020). Incidence of thrombotic complications in critically ill ICU patients with COVID-19. Thrombosis Research, 191, 145-7. https://doi.org/10.1016/j.thromres.2020.04.013

Kreuziger, L., Lee, A., Garcia, D., Cuker, A., Cushman, M., D. S. M. \& Connors, J. (2020). American Society of Hematology. COVID-19 and VTE/Anticoagulation: Frequently Asked Questions. American Society of Hematology. https://www.hematology.org/covid-19/covid-19-and-vteanticoagulation

Lever, R. \& Page, C. P. (2012). Non-anticoagulant Effects of Heparin: An Overview. In: Lever R, Mulloy B, Page CP, organizadores. Heparin - A Century of Progress, 281-305. http://link.springer.com/10.1007/978-3-642-23056-1_12

Levi, M., Thachil, J., Iba, T. \& Levy, J. H. (2020). Coagulation abnormalities and thrombosis in patients with COVID-19. The Lancet Haematology, 7 (6), e438-40. https://www.thelancet.com/journals/lanhae/article/PIIS2352-3026(20)30145-9/fulltext

Li, L., Huang, T., Wang, Y., Wang, Z., Liang, Y., Huang, T., Zhang, H., Sun, W., Wang, Y. (2020). COVID-19 patients' clinical characteristics, discharge rate, and fatality rate of meta-analysis. J Med Virol, 92 (6), 577-83. https://doi.org/10.1002/jmv.25757

Magro, G. (2020). Cytokine Storm: Is it the only major death factor in COVID-19 patients? Coagulation role. Medical Hypotheses, 142, 109829. https://pubmed.ncbi.nlm.nih.gov/32428809/ 
Marietta, M. et al. (2020). COVID-19 and haemostasis: a position paper from Italian Society on Thrombosis and Haemostasis, SISET. Blood Transfusion. https://doi.org/10.2450/2020.0083-2

Menezes-Rodrigues, F. S., Tavares, J. G. P., Oliveira. M. P. de, Carvalho, R. G.de, Errante P. R., Taha M. O., Fagundes, D. J. \& Caricati-Neto A. (2020). Anticoagulant and antiarrhythmic effects of heparin in the treatment of COVID-19 patients. J Thromb Haemost,18 (8), 2073-5. https://doi.org/10.1111/jth.14902

Mycroft-West, C. J., Su, D., Pagani, I., Rudd, T. R., Elli, S., Guimond, S. E., Miller, G., Meneghetti, M. C. Z, Nader, H. B., Li, Y., Nunes, Q. M., Procter, P., Mancini, N., Clementi, M., Bisio, A., Forsyth, N. R, Turnbull, J. E., Guerrini, M., Fernig, D. G., Vicenzi, E., Yates, E. A., Lima, M. A. \& Skidmore, M. A. (2020). Heparin Inhibits Cellular Invasion by SARS-CoV-2: Structural Dependence of the Interaction of the Spike S1 Receptor-Binding Domain with Heparin. Thromb Haemost, 120 (12):1700-15. https://doi.org/10.1101/2020.04.28.066761

Nascimento, J. H. P., Gomes, B. F. de O., Carmo, P. R. do, Petriz, J. L. F., Rizk, S. I., Costa, I. B. S. da S., Marcus, V. G. L., Fernando, B., Ludhmila, A. H \& Gláucia, M. M. de O. (2020). COVID-19 e Estado de Hipercoagulabilidade: Uma Nova Perspectiva Terapêutica. Arquivos Brasileiros de Cardiologia, 114 (5):829-33. https://www.scielo.br/j/abc/a/trcCwg8ncqpMwRgn8Hq7Bbw/?lang=pt

Nicolai, L., Leunig, A., Brambs, S., Kaiser, R., Weinberger, T., Weigand, M., Maximilian, M., Johannes, C. H., Stephan, L., Heiko, S., Clemens, S., Martina, R., Michael, Z., Dominik, H., Oliver K., Daniel, T., Bernhard, Z., Michael, V.B.-B., Stefan, K., Steffen, M., Kami \& P., Konstantin S. (2020). Immunothrombotic Dysregulation in COVID-19 Pneumonia Is Associated With Respiratory Failure and Coagulopathy. Circulation, 142 (12):1176-89. https://doi.org/10.1161/CIRCULATIONAHA.120.048488

Nissborg, E., Wahlgren, C-M. (2019). Anticoagulant Effect of Standard Dose Heparin During Peripheral Endovascular Intervention. Annals of Vascular Surgery, 60:286-92. https://doi.org/10.1016/j.avsg.2019.02.033

Obi, A. T., Barnes, G. D., Wakefield, T. W., Brown, S., Eliason, J. L., Arndt, E. \& Henke, P. K. (2020). Practical diagnosis and treatment of suspected venous thromboembolism during COVID-19 pandemic. Journal of Vascular Surgery: Venous and Lymphatic Disorders, 8 (4):526-34. https://doi.org/10.1016/j.jvsv.2020.04.009

Obi, A. T., Tignanelli, C. J., Jacobs, B. N., Arya S., Park, P. K., Wakefiel, T. W., Henke, P. K. \& Napolitano, L. M. (2019). Empirical systemic anticoagulation is associated with decreased venous thromboembolism in critically ill influenza A H1N1 acute respiratory distress syndrome patients. Journal of Vascular Surgery: Venous and Lymphatic Disorders, 7 (3), 317-24. https://doi.org/10.1016/j.jvsv.2018.08.010

Orsi, F. A., Paula, E. V.de, Santos, F.de O., Teruchkin, M. M., Campêlo, D. H. C., Mello, T. T., Chindamohi, M. C., Macedo, A. V. S., Rocha, A. T., Ramacciottino, E., Nascimento, A. C. K., Annichino-Bizzacchi, J., Lourenco, D. M., Guerra, J. C, de C., Rezendes, S. M. \& Filho, C. C. (2020). Guidance on diagnosis, prevention and treatment of thromboembolic complications in COVID-19: a position paper of the Brazilian Society of Thrombosis and Hemostasis and the Thrombosis and Hemostasis Committee of the Brazilian Association of Hematology, Hemotherapy and Cellular Therapy. Hematology, Transfusion and Cell Therapy, 42 (4), 300-8. https://doi.org/10.1016/j.htct.2020.06.001

Poggiali, E.,Bastoni, D., Bastoni, E., Vercelli, A. \& Magnacavallo A. (2020). Deep Vein Thrombosis and Pulmonary Embolism: Two Complications of COVID-19 Pneumonia? European Journal of Case Reports in Internal Medicine, 7 (5), 1. https://doi.org/10.12890/2020_001646

Porfidia, A. \& Pola, R. (2020). Venous thromboembolism and heparin use in COVID-19 patients: juggling between pragmatic choices, suggestions of medical societies and the lack of guidelines. J Thromb Thrombolysis, 50 (1), 68-71. https://doi.org/10.1007/s11239-020-02125-4

Ranucci, M., Ballotta, A., Di Dedda, U., Bayshnikova, E., Dei Poli, M., Resta, M., Falco, M., Albano, G. \& Menicanti, L. (2020). The procoagulant pattern of patients with COVID-19 acute respiratory distress syndrome. J Thromb Haemost, 18 (7), 1747-51. https://doi.org/10.1111/jth.14854

Soeiro, A. de M., Leal, T. de C.A.T., Pereira, M. de P., Lima, E. G., Figueiredo, A. C. B. da S., Petriz, J. L. F., Precoma, D. B. \& Serrano, C. V. J. (2020). Posicionamento sobre Uso de Antiplaquetários e Anticoagulantes nos Pacientes Infectados pelo Novo Coronavírus (COVID-19) - 2020. Arquivos Brasileiros de Cardiologia, 115 (2):292-301. https://doi.org/10.36660/abc.20200424

Sociedad Española de Trombosis y Hemostasia (2020). Recomendaciones de Tromboprofilaxis Y Tratamiento Antitrombótico em Pacientes con COVID-19. http://www.fasgo.org.ar/index.php/informacion-a-la-comunidad/2032-recomendaciones-de-tromboprofilaxis-y-tratamiento-antitrombotico-en-pacientes-concovid-19

Shi, C., Wang, C., Wang, H., Yang, C., Cai, F., Zeng, F., Cheng, F., Liu, Y., Zhou, T., Deng, B., Vlodavsky, I., Li, J-P. \& Zhang, Y. (2021). The potential of low molecular weight heparin to mitigate cytokine storm in severe COVID-19 patients: a retrospective clinical study. Pharmacology and Therapeutics. http://medrxiv.org/lookup/doi/10.1101/2020.03.28.20046144

Steffel, J., Verhamme, P., Potpara, T. S., Albaladejo, P., Antz, M., Desteghe, L., Haeusler, K. G., Oldgren, J., Reinecke, H., Roldan-Schilling, V., Rowell, N., Sinnaeve, P., Collins, R., Camm, A.J \& Heidbüchel, H. (2018). The 2018 European Heart Rhythm Association Practical Guide on the use of non-vitamin K antagonist oral anticoagulants in patients with atrial fibrillation. European Heart Journal, 39 (16), 1330-93. https://doi.org/10.1093/eurheartj/ehy136

Stoneham, S. M., Milne, K. M., Nuttall, E., Frew, G. H., Sturrock, B.R., Sivaloganathan H., Ladikou, E.E., Drage, S., Phillips, B., Chevassut, T. J. T. \& Eziefula, A. C. (2020). Thrombotic risk in COVID-19: a case series and case-control study. Clin Med, 20 (4), e76-81. https://doi.org/10.7861/clinmed.20200228

Tang, N., Bai, H., Chen, X., Gong, J., Li, D. \& Sun, Z. (2020). Anticoagulant treatment is associated with decreased mortality in severe coronavirus disease 2019 patients with coagulopathy. J Thromb Haemost, 18 (5), 1094-9. https://doi.org/10.1111/jth.14768

Tang, N, Li, D., Wang, X. \& Sun, Z. (2020) Abnormal coagulation parameters are associated with poor prognosis in patients with novel coronavirus pneumonia. J Thromb Haemost, 18 (4), 844-7. https://doi.org/10.1016/S0140-6736(20)30183-5

Testa, S., Paoletti, O., Giorgi-Pierfranceschi, M. \& Pan, A. (2020). Switch from oral anticoagulants to parenteral heparin in SARS-CoV-2 hospitalized patients. Intern Emerg Med, 15 (5), 751-3. https://doi.org/10.1007/s11739-020-02331-1 
Thachil, J., Tang, N., Gando, S., Falanga, A., Cattaneo, M., Levi, M., Clark, C. \& Iba, T. (2020a). ISTH interim guidance on recognition and management of coagulopathy in COVID-19. J Thromb Haemost, 18 (5), 1023-6. https://pubmed.ncbi.nlm.nih.gov/32338827/

Thachil, J., Tang, N., Gando, S., Falanga, A., Levi, M., Clark, C., Iba, T. \& Cattaneo, M. (2020b). Type and dose of heparin in Covid-19: Reply. J Thromb Haemost, 18 (8), 2063-4. https://doi.org/10.1111/jth.14870

Thachil, J. (2020). The versatile heparin in COVID-19. J Thromb Haemost, 18 (5):1020-2. https://doi.org/10.1111/jth.14821.

Vivas, D., Roldán, V., Esteve-Pastor, M. A., Roldán, I., Tello-Montoliu, A., Ruiz-Nodar, J. M., Cosín-Sales, J., Gámez, J. M., Consuegrai, L., Ferreiro, J. L. \& Marín, F. (2020). Recomendaciones sobre el tratamiento antitrombótico durante la pandemia COVID-19. Posicionamiento del Grupo de Trabajo de Trombosis Cardiovascular de la Sociedad Española de Cardiología. Revista Española de Cardiología, 73 (9), 749-57. https://doi.org/10.1016/j.recesp.2020.04.006

Wang, T., Chen, R., Liu, C., Liang, W., Guan, W., Tang, R., Nanshan, Z \& Shiyue, L. (2020). Attention should be paid to venous thromboembolism prophylaxis in the management of COVID-19. The Lancet Haematology, 7 (5), e362-3. https://doi.org/10.1016/S2352-3026(20)30109-5

Wichmann, D., Sperhake, J-P., Lütgehetmann, M., Steurer, S., Edler, C., Heinemann, A., Heinrich, F., Mushumba, H., Kniep, I., Schröder, A.S., Burdelski, C., Heer, G. de, Nierhaus, A., Frings, D., Pfefferle, S., Becker, H., Bredereke-Wiedling, H., Weerth, A. de, Paschen, H-R., Sheikhzadeh-Eggers, S., Stang, A., Schmiedel, S., Bokemeyer, C., Addo, M.M., Aepfelbacher, M., Püschel, K., Kluge, S. (2020). Autopsy Findings and Venous Thromboembolism in Patients With COVID-19: A Prospective Cohort Study. Annals of Internal Medicine, 173 (4), 268-77. https://doi.org/10.7326/M20-2003

World Health Organization (2021). Coronavirus disease (COVID-19) pandemic. https://www.who.int/emergencies/diseases/novel-coronavirus2019? adgroupsurvey $=\{$ adgroupsurvey $\} \&$ gclid=Cj0KCQjw1dGJBhD4ARIsANb6OdnD82y64IhGz6IJ5RrinIPSHNqAQSNw7CGfvutKsbIROpFAqgmyaK8a Ap51EALw_wcB

Wu, C., Chen, X., Cai, Y., Xia, J., Zhou, X., Xu, S., Huang, H., Zhang, L., Zhou, X., Du, C., Zhang, Y., Song, J., Wang, S., Chao, Y., Yang, Z., Xu, J., Zhou, X., Chen, D., Xiong, W., Xu, L., Zhou, F., Jiang, J., Bai, C., Zheng J. \& Song Y. (2020). Risk Factors Associated With Acute Respiratory Distress Syndrome and Death in Patients With Coronavirus Disease 2019 Pneumonia in Wuhan, China. JAMA Intern Med, 180 (7), 934. https://jamanetwork.com/journals/jamainternalmedicine/fullarticle/2763184

Whitlock, R. P., Sun, J. C., Fremes, S. E., Rubens, F. D., Teoh, K. H. (2012). Antithrombotic and Thrombolytic Therapy for Valvular Disease. Chest, 141 (2), e576S-e600S. https://doi.org/10.1378/chest.11-2305

Whyte, C. S., Morrow, G. B., Mitchell, J. L., Chowdary, P., Mutch, N. J. (2020). Fibrinolytic abnormalities in acute respiratory distress syndrome (ARDS) and versatility of thrombolytic drugs to treat COVID-19. J Thromb Haemost, 18 (7):1548-55. https://doi.org/10.1111/jth.14872

Ye, Q., Wang, B. \& Mao, J. (2020) The pathogenesis and treatment of the 'Cytokine Storm' in COVID-19. Journal of Infection, 80 (6), 607-13. https://doi.org/10.1016/j.jinf.2020.03.037

Yin, S., Huang, M., Li, D. \& Tang, N. (2020). Difference of coagulation features between severe pneumonia induced by SARS-CoV2 and non-SARS-CoV2. J Thromb Thrombolysis, 1-4. https://www.ncbi.nlm.nih.gov/pmc/articles/PMC7124128/

Yuki, K., Fujiogi, M. \& Koutsogiannaki S. (2020). COVID-19 pathophysiology: A review. Clinical Immunology, 215:108427. https://doi.org/10.1016/j.clim.2020.108427

Zehnder, J. L.(2017). Fármacos usados nos distúrbios de coagulação. In: Katzung, B.G., Trevor, A.J.,.Farmacologia básica e clínica. 13th ed., AMGH, Porto Alegre.

Zheng, Y. Y., Ma, Y. T., Zhang, J. Y \& Xie X. (2020). COVID-19 and the cardiovascular system. Nat Rev Cardiol, 17 (5), 259-60. https://doi.org/10.1038/s41569-020-0360-5

Zhou, F., Yu, T., Du, R., Fan, G., Liu, Y., Liu, Z., Xiang, J., Wang, Y., Song, B., Gu, X., Guan, L., Wei, Y., Li, H., Wu, X., Xu, J., Tu, S., Zhang, Y., Chen, H., Cao, B. (2020). Clinical course and risk factors for mortality of adult inpatients with COVID-19 in Wuhan, China: a retrospective cohort study. The Lancet, 395 (10229), 1054-62. https://doi.org/10.1016/S0140-6736(20)30566-3 